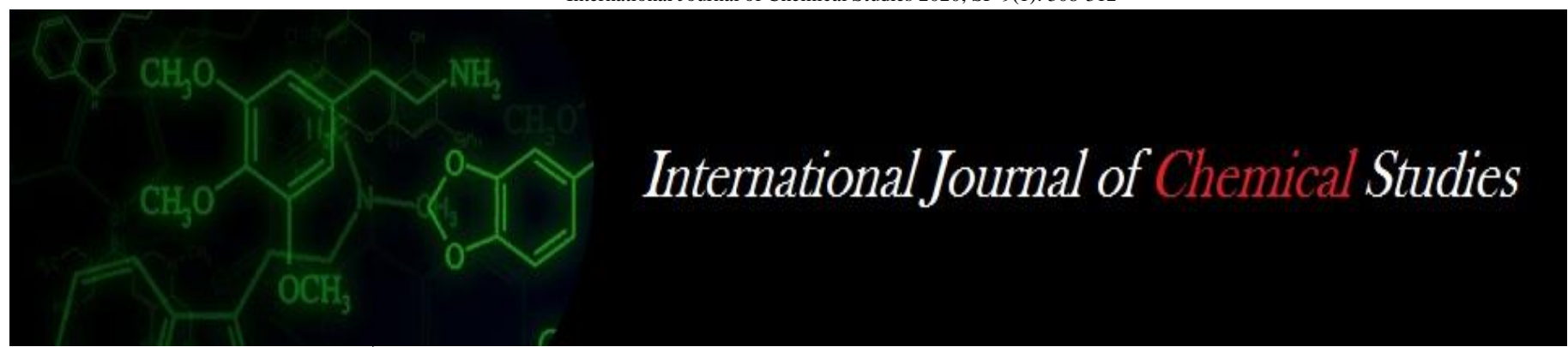

P-ISSN: 2349-8528

E-ISSN: 2321-4902

www.chemijournal.com

IJCS 2021; SP-9(1): 308-312

(C) 2021 IJCS

Received: 02-10-2020

Accepted: 15-11-2020

Anjali Kanth

Department of Foods and

Nutrition, College of Home

Science, G.B. Pant University of

Agriculture \& Technology,

Pantnagar, Uttarakhand, India

Kanchan Goswami

Department of Foods and

Nutrition, College of Home

Science, G.B. Pant University of

Agriculture \& Technology,

Pantnagar, Uttarakhand, India

Pushpa Shukla

Department of Foods and

Nutrition, College of Home

Science, G.B. Pant University of

Agriculture \& Technology,

Pantnagar, Uttarakhand, India

Corresponding Author:

Kanchan Goswami

Department of Foods and

Nutrition, College of Home

Science, G.B. Pant University of

Agriculture \& Technology,

Pantnagar, Uttarakhand, India

\section{Product formulation from black gram and its evaluation for nutritional and sensory quality}

\author{
Anjali Kanth, Kanchan Goswami and Pushpa Shukla
}

DOI: https://doi.org/10.22271/chemi.2021.v9.i1f.11748

\begin{abstract}
Black gram is cultivated in India and is the essential legume crops. It is used as whole, split beans and dehusked split beans ( $\mathrm{h} h \mathrm{al}$ ). Due to better nutrient content and availability, new improved varieties of black gram are being evolved and there is little information available on them. So, the purpose of the study is to develop product using whole black gram and dehusked black gram of same variety (Pant U31) and to assess the nutritional properties, shelf life and consumer acceptability of the developed product. Badi was prepared using whole black gram (Pant U-31) and was compared with dehusked black gram of same variety and was evaluated for sensory characteristics, nutrient composition and storage study for the period of 60 days. Results showed that during storage, obtained values were found to be in acceptable range for total plate count and it was observed that the badi packed in polyethylene pouches could be stored up to 2 months at room temperature safely. For sensory evaluation, the prepared badis were cooked in a vegetable curry preparation and was done using Nine Point Hedonic Scale and Score card method. Results of Nine Point Hedonic Scale showed that control badi curry was liked very much by $33.33 \%$ of panel members and badi curry prepared by whole black gram was liked very much by $46.66 \%$. Statistical analysis of data obtained by score card method showed that there was non-significant difference in overall acceptability between badi curry prepared with dehusked black gram (control) and whole black gram. Nutrient composition of whole black gram (Pant U-31) badi curry revealed that it contained higher amount of fibre $(3.31 \mathrm{~g})$, calcium $(60.87 \mathrm{mg} / 100 \mathrm{~g})$ and iron $(3.41 \mathrm{mg} / 100 \mathrm{~g})$ content than that of control (Dehusked black gram) badi curry of same variety.
\end{abstract}

Keywords: Black gram, shelf life, consumer acceptability, nutritional properties, nine point hedonic scale, score card method

\section{Introduction}

India is a major legume producing country in the world. Legumes serve as an economical source of complimentary proteins and also add variety to diet for human population. They contribute as high protein constituent in India (Sood et al., 2002) ${ }^{[22]}$. Legumes are valued for their low glycemic index and high protein content so they are generally included in the diets of Indian subcontinent (Khandelwal et al., 2010) ${ }^{[13]}$. Animal and plant proteins are commonly the two main sources of protein. Since animal proteins are costly, there is a need for alternative supplementation of protein by plant protein. Pulses contain protein of 220-250 g per kg whereas dry fish contain protein of $335 \mathrm{~g}$ per $\mathrm{kg}$. Thus pulses are considered as a "poor man's meat" (Nunes et al. 2006) ${ }^{[18]}$. The production and inclination of legumes vary in different countries (Ofuya and Akhidue, 2005) ${ }^{[19]}$. In India legumes are cultivated over an area of 24.8 million hectares with 17.2 million tonnes produced annually (DAC, New Delhi, 2015) ${ }^{[5]}$. Consumption of legume is higher in those parts of the world, where animal proteins are limited and costly. Being an inexpensive protein source, legumes can be replaced to meat and play an important role in eradicating protein-energy malnutrition. They are also a good source of vitamins, minerals and dietary fibre (Tharanathan and Mahadevamma, 2003) [24].

Pulses belonging to the family of leguminosae are the eatable portions of pod bearing plants are cultivated globally. Seeds of whole legume plant are of major concern to human as they are a rich source of protein ranging from $20-50 \%$ (Singh et al. 2004) ${ }^{[21]}$. Pulses are an excellent source of protein and amino acids and certain micronutrients such as iron and zinc. They also have low glycemic index and no cholesterol (Food and Agriculture Organization, 2016) ${ }^{[7]}$. Legumes reduce the risk of cardiovascular disease and diabetes (Jacobs \& Gallaher, 2004) ${ }^{[11]}$ mostly by the presence of phenolics and soluble dietary fiber (Enujiugha, 2010) ${ }^{[6]}$. 
Pulses enhance the soil fertility and also used for green manure as fodder for livestock (Aggarwal et al., 2004) ${ }^{[1]}$. Among all the legumes, black gram (Vigna mungo L.) is an essential legume crop.

It is consumed in Indian diet and Western diet since it is a very rich source of protein and performs an essential role in the diet of human nutrition. Proteins of black gram are digested in an easy manner and consist of satisfactory amount of sulfur containing amino acids. They are rich in vitamins and phosphoric acid. It is generally used as whole, split beans and dehusked split beans (dal) (Gowda, 2006) ${ }^{[9]}$.

Black gram (Vigna Mungo L.), is one of the important pulses crop, grown throughout the country. The crop is resistant to adverse climatic conditions and improve the soil fertility by fixing atmospheric nitrogen in the soil. It has been reported that the crop produces equivalent to $22.10 \mathrm{~kg}$ of N/ha., which has been estimated to be supplement of 59 thousand tonnes of urea annually. The pulse 'Black gram' plays an important role in Indian diet, as it contains vegetable protein and supplement to cereal based diet. It contains about $26 \%$ protein, which is almost three times that of cereals and other minerals and vitamins. Besides, it is also used as nutritive fodder, specially for milch animals. Madhya Pradesh, Uttar Pradesh and Andhra Pradesh are major black gram growing states areawise. The highest yield was recorded by the state of Bihar (898 kg/ha) followed by Sikkim $(895 \mathrm{~kg} / \mathrm{ha})$ and Jharkhand $(890 \mathrm{~kg} / \mathrm{ha})$. The National yield average is $585 \mathrm{~kg} / \mathrm{ha}$. The lowest yield was recorded in the state of Chhattisgarh (309 $\mathrm{kg} / \mathrm{ha}$ ) followed by Odisha (326 kg/ha) and J\&K (385 kg/ha) (https://vikaspedia.in/agriculture/crop-production/package-of practices/pulses/blackgram-and-greengram).

According to Manay and Shadaksharaswamy (1987) ${ }^{[16]}$, black gram contains mucilaginous arabinoglactins which is an essential constituent in dosa, badi, idli and several other food preparations. It helps in making sweet dishes like imarti and vada. It is also eaten as snacks in fried and salted form.

Papads, thin wafer like products prepared from black gram or combination of black gram with other pulses with and without spices are made in small scale industries or at homes (Srivatsava, 2015) ${ }^{[23]}$. Black gram flour was incorporated in buffalo meat burgers and it was stated to enhance burger quality (Modi et al., 2004). Flour of black gram was added to biscuits to enhance its nutritional quality (Patel and Venkateswara, 1995) ${ }^{[20]}$. To increase productivity and enhance its utilization, new improved varieties of black gram are being evolved. Due to less information regarding their utilization in food present study was done to prepare product from whole and dehusked black gram.

\section{Materials and Methods}

Procurement of Raw Materials: The improved varieties (Pant U-8, Pant U-9, Pant U-31 and Pant U-35) of Black gram (Phaseolus mungo or Vigna mungo) were obtained from CRC (Crop Research Centre), G.B. Pant University of Agriculture and Technology, Pantnagar. The description of four black gram varieties under study is presented in Table I. Other ingredients used for badi curry preparations were purchased from local market of Pantnagar.

Table 1: Description of black gram varieties

\begin{tabular}{|c|c|c|c|c|c|c|c|c|c|}
\hline \multirow{2}{*}{$\begin{array}{l}\text { Varieties of } \\
\text { black gram }\end{array}$} & \multirow{2}{*}{ Origin } & \multicolumn{2}{|c|}{ Pod } & \multicolumn{2}{|c|}{ Seeds } & \multicolumn{3}{c|}{ Agronomic traits } \\
\cline { 3 - 9 } & $\begin{array}{c}\text { Color of } \\
\text { immature pod }\end{array}$ & $\begin{array}{c}\text { Color of } \\
\text { mature pod }\end{array}$ & Color & Shape & Size & Plant ht. (cm) & $\begin{array}{c}\text { No. of pods/ } \\
\text { plant }\end{array}$ & $\begin{array}{c}\text { No. of seeds/ } \\
\text { pod }\end{array}$ \\
\hline Pant U-8 & Pantnagar & Green & Black & Black & Oblong & Large & Mean: 43.1 Range: $37-66$ & $34-44$ & $5-7$ \\
\hline Pant U-9 & Pantnagar & Green & Black & Black & Oblong & Large & Mean: 44.6 Range: $31-64$ & $31-49$ & $5-7$ \\
\hline Pant U-31 & Pantnagar & Green & Black & Black & Oblong & Large & Mean: 71.4 Range: $54.2-90.2$ & $34-45$ & $5-7$ \\
\hline Pant U-35 & Pantnagar & Green & Black & Black & Oblong & Large & 100 & - & - \\
\hline
\end{tabular}

\section{Product formulation}

Nutritional evaluation of four varieties was carried out. The variety (Pant U-31) with the highest protein content was selected for product formulation. Badi was prepared using whole black gram (Pant U-31) and was compared with dehusked black gram of same variety and was analyzed for nutrient composition and storage study.

\section{Preparation of $\mathrm{Badi}$}

Whole Black gram was washed thoroughly and soaked in double the amount of water for 12-13h. After draining and washing, the whole black gram was ground to paste by using household grinder while the control black gram was rubbed with hands to remove the seed coat and then was ground to paste.

The thick wet paste was made light and fluffy by incorporating air by wiping continuously with hand. The fluffy batter was divided with the help of hand into small balls and kept on the greased drying tray followed by drying in a cabinet tray drier at a temperature of $60 \pm 5{ }^{\circ} \mathrm{C}$ for $14-16 \mathrm{~h}$ till no further water loss occurred. The dried samples were stored in polyethylene bags for further analysis which included storage study and organoleptic evaluation (Kaur and Aggarwal, 2015) ${ }^{[12]}$.

\section{Storage study of Badi}

Total Viable Count (APHA 1984) ${ }^{[4]}$ : Total bacterial count of the samples was determined using Standard Plate Count (SPC) technique as given in compendium of methods for microbiological examination of foods (APHA, 1984) ${ }^{[4]}$. This technique gives total number of viable cells of bacteria present in the sample, therefore also called as total viable cell count (TVC) technique or serial dilution technique.

Moisture: Moisture content was determined using the procedure given by AOAC (1995) ${ }^{[3]}$.

\section{Preparation of Badi curry}

For sensory evaluation, curry preparation was made using prepared baris from whole black gram and dehusked black gram. They were pressure cooked for 15 minutes and then, served hot to the panelists.

\section{The ingredients used were}

$\begin{array}{lc}\text { Ingredients } & \text { Quantity } \\ \text { Badi } & 50 \mathrm{~g} \\ \text { Onion } & 75 \mathrm{~g} \\ \text { Garlic paste } & 10 \mathrm{~g} \\ \text { Water } & 400 \mathrm{ml} \\ \text { Oil } & 15 \mathrm{ml} \\ \text { Salt } & 3 \mathrm{~g} \\ \text { Spices (red chilli powder, Garam masala, coriander powder) } & 7 \mathrm{~g}\end{array}$




\section{Method}

- Badis were roasted in oil till light brown in colour and kept aside.

- The oil was heated in a container and onion was added and roasted till golden brown.

- To this onion paste was added and fried for another 3 min. then spices and salt were added.

- Fried badis were added the last followed by addition of $400 \mathrm{ml}$ water and cooking it for 15-20 min.

\section{Sensory evaluation of Badi curry made from dehusked} black gram and whole black gram

The prepared badi curry were evaluated for sensory characteristics using nine point hedonic scale and sensory score card (Amerine et al., 1965) ${ }^{[2]}$ by semi trained panel consisting of 15 members from the Department of Foods and Nutrition.

\section{Nutritional evaluation of developed product}

The nutritive value of badi curry was calculated by using the data available in Indian Food Composition Tables by Longvah et al. (2017) ${ }^{[15]}$. The nutritive value of whole black gram was used from the result obtained in the present study. Energy, crude protein, crude fat, crude fibre, carbohydrates, physiological energy, calcium and Iron were calculated.

\section{Statistical analysis}

The statistical tools used for the analysis of the above data were Mean \pm S.D and One-way ANOVA (Analysis of variance) Snedecor and Cochran (1980). Storage stability of product were analyzed using these procedures. The aim of the analysis was to identify the significant difference in storage stability used in the present study.

\section{Results and Discussion}

\section{Product development and evaluation}

$200 \mathrm{gm}$ of whole black gram were soaked in double the amount of water. The weight of black gram after soaking for $12 \mathrm{~h}$ was $388 \mathrm{~g}$. Total $334 \mathrm{gm}$ of badi was prepared from whole black gram.

\section{Storage study of Badi}

Black gram badi of improved variety (Pant U-31) which contained highest amount of protein were packed in High density polyethylene bags (HDPE) and were stored for two months at room temperature $\left(17^{\circ} \mathrm{C}-24^{\circ} \mathrm{C}\right)$. The stored sample was evaluated for 60 days at 15 day interval. The shelf life was evaluated on the basis of moisture content and total viable count. The results obtained are presented in Table 2 and Table 3.

\section{Total viable count}

There were less than 30 colonies in badi on 0 day of storage period. Microbial load increased with increasing time of storage. Microbial load reaches up to $1.71 \times 10^{3} \mathrm{cfu} / \mathrm{g}$ after 60 days of storage at room temperature. The obtained values were found to be in acceptable range for total plate count. Statistical analysis of data showed that there is significant difference during the storage period for 60 days. In general, the total viable count for papad is reported as $9.15 \times 10^{2} \mathrm{cfu} / \mathrm{g}$ (Veena, 2012) ${ }^{[25]}$.

Table 2: Total Plate Count of Badi during the Storage Period

\begin{tabular}{|c|c|c|c|c|c|c|c|}
\hline Total plate count (TPC) $(\mathbf{c f u} / \mathbf{g})$ & \multicolumn{7}{c|}{ Storage period } \\
\hline Product & 0 Days & 15 Days & 30 Days & 45 Days & 60 Days & S.Em.. & CD at 5\% \\
\hline$B a d i$ & $<30^{\mathrm{a}}$ & $0.94 \times 10^{3 \mathrm{~b}}$ & $1.13 \times 10^{3 \mathrm{c}}$ & $1.47 \times 10^{3 \mathrm{~d}}$ & $1.71 \times 10^{\mathrm{e}}$ & 0.401 & 0.126 \\
\hline
\end{tabular}

All results are mean \pm standard deviation for three individual determinations.

Means in each row by different letters $(\mathrm{a}, \mathrm{b}, \mathrm{c}, \mathrm{d}, \mathrm{e})$ are significantly different $(P \leq 0.05)$

\section{Moisture Content}

The moisture content of badi increased with increasing time of storage at room temperature. The moisture content increased from 6.93 per cent on the starting day of study to 7.3 per cent after 60 days. There was significant difference in badi on zero day, 30 days, 45 days and 60 days in moisture content but there was non-significant difference between 0 day and 15 days. It was observed that the badi packed in polyethylene pouches could be stored up to 2 months at room temperature safely. In deciding the storage stability of badi, moisture plays an essential factor and should be less than 11 per cent to prevent them from microbes and fungus (Kulkarni et al., 1997) ${ }^{[14]}$.

Table 3: Moisture Content of Badi

\begin{tabular}{|c|c|c|c|c|c|c|c|}
\hline \multicolumn{7}{|c|}{ Moisture content (\%) Storage period } \\
\hline Product & 0 Day & 15 Days & 30 Days & 45 Days & 60 Days & S.Em. \pm & CD at 5\% \\
\hline Badi & $6.93 \pm 0.10^{\mathrm{a}}$ & $7.00 \pm 0.05^{\mathrm{a}}$ & $7.10 \pm 0.05^{\mathrm{b}}$ & $7.18 \pm 0.08^{\mathrm{c}}$ & $7.30 \pm 0.10^{\mathrm{d}}$ & 0.459 & 0.144 \\
\hline
\end{tabular}

All results are mean \pm standard deviation for three individual determinations.

Means in each row by different letters $(a, b, c, d)$ are significantly different $(P \leq 0.05)$

\section{Sensory evaluation of badi curry}

The sensory evaluation of badi curry prepared whole black gram and dehusked black gram (control) was conducted using nine point hedonic scale and score card method by 15 semi trained panels from the Department of Foods and Nutrition.

\section{Sensory evaluation using Nine Point Hedonic Scale}

The results of sensory evaluation of badi curry using Nine Point Hedonic Scale have been presented in Table 4. Sensory evaluation of badi curry by Nine Point Hedonic Scale taking black gram of one improved variety (Pant U-31) which is highest in protein showed that badi curry prepared from whole black gram was liked very much by 46.66 per cent of the panel members, 26.66 per cent of the panel members liked it moderately, 20 per cent of the evaluators liked it slightly and 6.66 per cent of the panel members neither liked it nor disliked it. Control badi curry from dehusked black gram was liked very much by 33.33 per cent of the panel members, 46.67 per cent of the panel members liked it moderately, 13.33 per cent of the panel members liked it slightly and 6.67 per cent of the members disliked it. 
Table 4: Sensory Score of Badi Curry of Selected Variety (Pant U-31) of Whole Black Gram and Dehusked Black Gram (control) Using Nine Point Hedonic Scale

\begin{tabular}{|c|c|c|c|c|c|c|}
\hline Scale & Liked extremely & Liked very much & Liked moderately & Liked slightly & Neither like nor dislike & Disliked slightly \\
\hline Product & - & $33.33 \%$ & $46.66 \%$ & $13.33 \%$ & - & $6.66 \%$ \\
\hline A (Pant U-31) (Control) & - & $46.66 \%$ & $26.66 \%$ & $20 \%$ & $6.66 \%$ & - \\
\hline B (Pant U-31) & \multicolumn{1}{|l}{} & & & - \\
\hline
\end{tabular}

Sensory score of badi curry prepared from improved variety (Pant U-31) of dehusked black gram (Control) and whole black gram using score card method

The prepared badi curry were further evaluated for their sensory quality using Score Card method for five parameters namely; taste, color, appearance, sponginess, flavour and overall acceptability. The data have been presented in Table5.

\section{Taste}

Mean sensory score for taste of control badi curry prepared with improved variety of dehusked black gram (Pant U-31) ranged from 7.67 to 8.85 , whereas for the badi curry made from improved variety of whole black gram (Pant U-31) ranged from 8.67 to 8.49 . Control badi curry obtained a mean score of 7.66 whereas curry prepared from whole black gram obtained a mean score of 7.66. Statistically non-significant difference was found in the taste of curry prepared with dehusked black gram (control) and whole black gram badi.

\section{Colour}

Mean sensory score for colour of control curry prepared with improved variety of dehusked black gram badi (Pant U-31) ranged from 8.07 to 8.87 , whereas for the curry made from improved variety of whole black gram badi (Pant U-31) ranged from 7.27 to 8.55 . Control curry obtained a mean score of 8.06 whereas curry prepared from whole black gram badi obtained a mean score of 7.26. Statistical analysis of data showed that dehusked black gram curry (control) differed significantly in colour from whole black gram badi curry.

\section{Appearance}

Mean sensory score for appearance of control badi curry prepared with improved variety of dehusked black gram (Pant U-31) ranged from 7.93 to 8.16 , whereas for the curry made from improved variety of whole black gram (Pant U-31) ranged from 7.07 to 8.23 . Control badi curry obtained a mean score of 7.93 whereas badi curry prepared from whole black gram obtained a mean score of 7.06. Statistical analysis of data showed that dehusked black gram badi curry (control) differed significantly in appearance from whole black gram badi curry.

\section{Sponginess}

Mean sensory score for sponginess of control badi curry prepared with improved variety of dehusked black gram (Pant U-31) ranged from 7.53 to 8.27 , whereas for the badi curry made from improved variety of whole black gram (Pant U-31) ranged from 6.13 to 7.49 . Control badi curry obtained a mean score of 7.53 whereas badi curry prepared from whole black gram obtained a mean score of 6.13. Statistical analysis of data showed that dehusked black gram badi curry (control) differed significantly in sponginess from whole black gram badi curry.

\section{Flavour}

Mean sensory score for flavour of control badi curry prepared with improved variety of dehusked black gram (Pant U-31) ranged from 7.07 to 8.56 , whereas for the curry made from improved variety of whole black gram (Pant U-31) ranged from 7.20 to 8.06. Control badi curry obtained a mean score of 7.06 whereas curry prepared from whole black gram obtained a mean score of 7.2. Statistically non-significant difference was found in the flavour of curry prepared with dehusked black gram (control) and whole black gram badi.

\section{Overall acceptability}

Mean sensory score for overall acceptability of control badi curry prepared with improved variety of dehusked black gram (Pant U-31) ranged from 7.47 to 8.53 , whereas for the badi curry made from improved variety of whole black gram (Pant U-31) ranged from 7.37 to 8.34 . Control badi curry obtained a mean score of 7.46 whereas curry prepared from whole black gram obtained a mean score of 7.36. Statistically nonsignificant difference was found in the overall acceptability of badi curry prepared with dehusked black gram (control) and whole black gram.

Table 5: Sensory score of Badi curry of selected variety (Pant U-31) of whole black gram and dehusked black gram (control) using score card method

\begin{tabular}{|c|c|c|c|c|}
\hline Product & \multirow{2}{*}{ Dehusked black gram (Control) Pant U-31 } & \multirow{2}{*}{ Whole black gram Pant U-31 } & S.Em \pm & CD at 5\% \\
\hline Attributes & $7.67 \pm 1.18^{\mathrm{a}}$ & $7.67 \pm 0.82^{\mathrm{a}}$ & 0.261 & 0.756 \\
\hline Taste & $8.07 \pm 0.80^{\mathrm{a}}$ & $7.27 \pm 1.28^{\mathrm{b}}$ & 0.275 & 0.797 \\
\hline Colour & $7.93 \pm 0.23^{\mathrm{a}}$ & $7.07 \pm 1.16^{\mathrm{b}}$ & 0.266 & 0.772 \\
\hline Appearance & $7.53 \pm 0.74^{\mathrm{a}}$ & $6.13 \pm 1.36^{\mathrm{b}}$ & 0.282 & 0.817 \\
\hline Sponginess & $7.07 \pm 1.49^{\mathrm{a}}$ & $7.20 \pm 0.86^{\mathrm{a}}$ & 0.313 & 0.908 \\
\hline Flavour & $7.47 \pm 1.06^{\mathrm{a}}$ & $7.37 \pm 0.97^{\mathrm{a}}$ & 0.262 & 0.760 \\
\hline Overall Acceptability & \multicolumn{2}{c}{} \\
\hline
\end{tabular}

All results are mean \pm standard deviation for three individual determinations.

Means in each row by different letters are significantly different $(P \leq 0.05)$

Nutritive value of improved variety (pant $u-31$ ) of whole black gram and dehusked black gram Badi Curry (Control)

Nutritive value of improved variety (Pant U-31) whole black gram badi curry and dehusked black gram badi curry (control) per $100 \mathrm{~g}$ was calculated by using the data available in Indian Food Composition Tables by Longvah et al. (2017) [15] whereas fibre content was calculated by using the data available in Nutritive value of Indian Foods by Gopalan et al. (2011) ${ }^{[8]}$. Results of nutritive value of dehusked (control) and whole black gram badi curry have been presented in Table 6 . Nutritive value of badi curry prepared from dehusked black 
gram i.e. control and whole black gram showed that fibre, calcium and iron content of whole black gram badi curry were higher than that of badi curry prepared from dehusked black gram while protein, fat, carbohydrate and energy content were higher in badi curry prepared from dehusked black gram.

Table 6: Nutritive value of selected variety (Pant U-31) of whole black gram Badi curry and dehusked black gram Badi curry (Control) per 100g

\begin{tabular}{|c|c|c|c|c|c|c|c|}
\hline Products & Protein (g) & Fat (g) & Fibre (g) & Carbohydrates (g) & Energy (kcal) & Calcium (mg) & Iron(mg) \\
\hline Dehusked black gram (Control) & 13.34 & 1.04 & 1.13 & 34.86 & 880.55 & 45.61 & 2.76 \\
\hline Whole Black gram & 12.80 & 0.98 & 3.31 & 31.35 & 812.05 & 60.86 & 3.41 \\
\hline
\end{tabular}

\section{Conclusion}

In the present study results of shelf life of badi stored at room temperature revealed that total plate count increased from $<30$ to $1.76 \times 10^{3} \mathrm{cfu} / \mathrm{g}$. Moisture content increased from $6.93 \%$ to $7.3 \%$. However, the values obtained in the present study fall within the acceptable limit. For sensory evaluation, the prepared badis were cooked in a vegetable curry preparation and was done using Nine Point Hedonic Scale and Score card method. Results of Nine Point Hedonic Scale showed that control badi curry was liked very much by $33.33 \%$ of panel members and badi curry prepared by whole black gram was liked very much by $46.66 \%$. Statistical analysis of data obtained by score card method showed that there was nonsignificant difference in overall acceptability between badi curry prepared with dehusked black gram (control) and whole black gram. Nutrient composition of Pant U-31 badi curry revealed that it contained higher amount of fibre $(3.31 \mathrm{~g})$, calcium $(60.87 \mathrm{mg} / 100 \mathrm{~g})$ and iron $(3.41 \mathrm{mg} / 100 \mathrm{~g})$ content than that of control badi curry. To maximize its utilization more products can be formulated from black gram.

\section{References}

1. Aggarwal V, Singh N, Kamboj SS, Brar PS. Some properties of seeds and starches separated from different Indian pea cultivars, Food Chemistry 2004;85:585-590.

2. Amerine MA, Pangborn RM, Roseller EB. Principles of sensory evaluation of foods, Academic Press, New York 1965, 265.

3. AOAC. Official Methods of Analysis of the Association of Official Analytical Chemists, 16th ed., AOAC, Washington, DC 1995.

4. APHA. Compendium of Methods for Microbiologocal Examination of Foods, in Vanderzent, C. and Toesses, S. (Eds), American Public Health association, Washington, DC 1984, 919-927.

5. Department of Agriculture and Coorporation (DAC). Directorate of Extension and Statistics, Department of Agriculture and Coorporation, New Delhi 2015.

6. Enujiugha $\mathrm{V}$. The antioxidant and free radical-scavenging capacity of phenolics from African loctus bean seeds, Advances in Food Science 2010;32(2):88-93.

7. FAO. International Year of Pulses, also available at 2016. http://www.fao.org/3/ai6690e.pdf

8. Gopalan C, Ramashastri B, Balasubramanian SC. Nutritive value of Indian Foods, National Institute of Nutrition, Indian Council of Medical Research, Hyderabad, India 2011, 48.

9. Gowda G. Improving Nutritive Value of Black Gram by Biochemical and Biotechnological Techniques, Thesis, Ph.D. Gulbarga University, Gulbarga 2006, 333.

10. https://vikaspedia.in/agriculture/cropproduction/package-of-practices/pulses/blackgram-andgreengram accessed onn January 20, 2021.

11. Jacobs DR, Gallahar DD. Whole grain intake and cardiovascular diseases: A review, Current Atherosclerosis reports 2004;6:415-423.
12. Kaur S, Aggarwal P. Preparation and Evaluation of Aloo wari- A novel nutritious traditional fermented product, International Journal of Food Fermentation Technology 2015;5(1):83-90.

13. Khandelwal S, Udipi SA, Ghugre P. Polyphenols and tannins in Indian pulses: effect of soaking, germination and pressure cooking, Food Research International 2010;43:526-530.

14. Kulkarni SG, Manan JK, Agarwal MD, Shukia IC. Studies on physic-chemical composition, packaging and storage of black gram and green gram wari prepared in Uttar Pradesh, Journal of Food Science and Technology 1997;34(2):119-122.

15. Longvah T, Ananthan R, Bhaskarachary K, Venkaiah K. Indian Food Composition Tables, National Institute of Nutrition, Indian Council of Medical Research Telangana, India 2017.

16. Manay N, Shadaksharaswamy M. Foods Facts and Principals. Wiley eastern limited 1987, 291-292.

17. Modi VK, Mahendrakar NS, Narasimha Rao D, Sachindra NM. Quality of buffalo meat burger containing legume flours as binders, Meat Science 2003;66:143-149.

18. Nunes MC, Raymundo A, Sousa I. Gelled vegetables desserts containing pea protein, k-carrangeenan and starch, European Food Research and Technology 2006;222:622-628.

19. Ofuya ZM, Akhidue V. The Role of Pulses in Human Nutrition: A Review, Journal of Applied Sciences and Environmental Management 2005;9(3):99-104.

20. Patel MM, Venkateshwar Rao G. Effect of Untreated, Roasted and Germinated Black Gram (Phaseolus mungo) Flours on the Physicochemical and Biscuit (cookie) Making Characteristics of Soft Wheat Flour, Journal of Grain Science 1995;22:285-291.

21. Singh N, Sandhu KS, Kaur M. Characteristics of starches from Indian Chickpea (Cicer arietinum L.) cultivars, Journal of Food Engineering 2004;63(4):441-449.

22. Sood M, Malhotra SR, Sood BC. Effect of processing and cooking on proximate composition of chickpea varieties, Journal of Food Science and Technology 2002;39:69-71.

23. Srivastava G. Pulses handbook 2015. Commodityindia.com.

24. Tharanatan RN, Mahadevamma S. Grain legumes-a boon to human nutrition, Trends in Food and Science Technology 2003;14:507-518.

25. Veena B, Reddy BS, Sharan S. Effect of Incorporation of Soy Flour on the Quality of Papad, Journal of Biology, Agriculture and Healthcare 2012;2(5):119-126. 